\title{
May 1968, Sartre and Sarkozy
}

\author{
JeAn-Pierre Boulé
}

Together, everything becomes possible (Nicolas Sarkozy). ${ }^{1}$

At first sight, it seems strange to have associated these two names in an article on May 1968. The impact of May '68 on Jean-Paul Sartre initially appeared to be non-existent; however in retrospect it appears to have exerted a profound influence upon him. Nicolas Sarkozy, the French president, was thirteen in 1968. Allegedly, he wanted to attend the $30^{\text {th }}$ May pro-de Gaulle demonstration, but his mother ensured that he was kept in school to prevent him from going. He was further associated with the events due to the fact that he was a law student in the mid-1970s at Nanterre University, where the student movement had begun and where Daniel Cohn-Bendit had been a sociology student. And yet again, many will remember the (in)famous speech Sarkozy gave in Bercy in April 2007 prior to the second round of voting in the French Presidential elections when he launched into virulent attack on May '68, concluding that he wanted once and for all to dispose of the spirit of May ' $68 .{ }^{2}$ My argument is that while arguing this standpoint, Sarkozy has appropriated left-wing rhetoric in order to convince his audience, and this is what I aim to demonstrate in this article. I am not at any point arguing that Sartre has directly influenced Sarkozy, simply that Sarkozy has appropriated left-wing rhetoric to pursue a right-wing agenda, and that we can see this through a study of Sartre. 
There are a number of parallels between Sarkozy's actions as Minister of the Interior and presidential candidate, and the lessons Sartre drew from May '68. Both men saw the need to reach out to a wider public; both men understood the value of praxis (political action), and both men asked themselves how to make people feel solidarity amongst disparate groups, what Sartre will call groups-in-fusion. Where Sartre saw the emergence of the new intellectual, the parallel with Sarkozy is the new politician. I will start by examining the influence of May '68 on Sartre before turning my attention to Sarkozy. I will then highlight the differences and similarities between them before concluding with a discussion of what lies behind Sarkozy's attack on May '68.

By the mid-1940s, Sartre was well aware that he was essentially a bourgeois writer writing for a bourgeois public. In "Qu'est-ce que la littérature?" published in Les Temps Modernes in 1946, Sartre was something of a trail-blazer when he decided to use the mass media (radio, newspapers, periodicals) in order to communicate with a wider public. He no longer wanted to write exclusively for a bourgeois audience but to reach out to the masses. On the one hand, this can be analyzed as Sartre breaking away from the sacrosanct status of the novel, a tradition embodied by nineteenth century writers such as Flaubert. On the other hand, the rationale for Sartre's attitude remained very traditional: "It is not acceptable to lower our standards to seduce our audience, but on the contrary, to reveal to the public its own demands and to raise these gradually, until it has a need to read" (“Qu'est-ce que la littérature?" 292). ${ }^{3}$ In other words, Sartre's commitment to using the mass media in 1946 reflected his wish to preserve the status of the written work. He wanted to conquer a public of non-readers and entice them to 
start reading his novels. In practice, as he admitted in 1972 when reflecting on the post-war period, Sartre was obliged to revise his assumption according to which he could widen his public and reach out to the masses by using the mass media alone (Astruc and Contat 85). Immediately after the Liberation, the elections revealed the Parti Communiste Francais (PCF) to be the party of the workers and Sartre needed their support to widen his public. Thus, in 1946, he realized that unless he worked alongside the PCF and could therefore communicate with the masses, he would be condemned to write primarily for a bourgeois public (Astruc and Contat 85). Sartre, being distrustful of the mass media, decided the way to reach out to a wider audience was to be endorsed by the PCF.

From 1952 when he wrote "Les communistes et la paix," Sartre became, according to his own expression, a fellow-traveller of the Communist Party until the Soviet invasion of Hungary four years later, which he condemned in an interview. But whether he ever did, even when he was a fellow traveler, communicate with the workers through the PCF is another matter. Following the Soviet invasion of Hungary, he wrote "La fantôme de Staline," wherein he explicitly dissociated himself from the Communist party. In so doing, Sartre felt that he had isolated himself from the workers (and had to abandon the idea of communicating with them through the Communist Party), even though by 1956, especially after the invasion of Hungary, the PCF was no longer the party of the working class in the way that it could, justifiably, have been in 1945-1946.

Thereafter, during a period of reflection on Marxism, Sartre started to write the Critique de la raison dialectique, published in 1960, in which he redefined his position on Communism 
and the Soviet Union. He also reflected upon notions of group action by looking at past historical events, notably the French Revolution, defining a group-in-fusion as a group in the process of being constituted by the dissolution of seriality (which he calls the Apocalypse), under the pressure of an opposing praxis. Through this concept, Sartre developed the theoretical concept of reciprocity.

It is only in Critique de la raison dialectique that reciprocity appears in Sartre's theoretical work. The notion of reciprocity is explicitly denied in L'Être et le néant published in 1943, where Sartre's being-for-others is first and foremost an object. Hence there can be no reciprocity between two subjects: "From the moment I exist, I establish a de facto limit to the freedom of the Other" ("Qu'est-ce que la littérature" 292). ${ }^{4}$ In L'Être et le néant in 1943, Sartre was convinced that two subjects could have only a relation of subject and object, hence his theory of objectifying the Other. The Other was an obstacle to one's freedom; now in 1960 in the Critique, he or she becomes necessary to the realization of this freedom, made possible by the concept of reciprocity. The Other becomes a means to an end, and not my end because he/she is praxis. Human relations (positive or negative) are reciprocal, because the praxis of one individual (his or her organizing project transformed into action) recognizes the praxis of the other (Sartre, Critique de la raison dialectique 207). The concept of praxis is a cornerstone to Sartre's understanding of reciprocity, as well as the concept of dialectics. The philosophical question is initially how one passes from a quasi-object to an object-subject and to a subjectobject (Sartre, Situations, IX 88). Sartre can allow himself to commit through language since "the 
human voice is given as praxis and the listener becomes the object of that praxis ... it is a univocal relation of interiority" (Critique de la raison dialectique 321$)^{5}$

In 1965 Sartre gave a series of lectures in Japan where he reflected upon the role, not of the writer, but of the intellectual, using his recent work on Marxist analysis (Situations, VIII 375455). He claimed that the intellectual had become a technician of practical knowledge whose goal was to facilitate the proletarian awakening, but who must also be wary of the distinction between the particular and the universal. ${ }^{6}$ If the intellectual claims to be the guardian of the universal, he or she thus reduces him/herself to representing a specific class, falling into the old illusion of the bourgeoisie thinking it represents a universal class (Sartre, Situations, VIII 387, 420, 421). The events of May '68 were going to make Sartre revise once more his definition of the intellectual.

The Critique de la raison dialectique was an important reference work for the actors of May '68. Epistémon, the pseudonym for a professor of psychology, declared that it was a premonitory work which allowed one to think the revolution of May, in particular Sartre's theories on alienated freedom, the practico-inert, the concepts of group and creative freedom ("Entretien avec Epistémon" IV). Cohn-Bendit himself acknowledged that the vast majority of the militants taking part in the Movement of March $22^{\text {nd }}$ had read Sartre (Contat and Rybalka 462).

Using periodicals, newspapers and radio, Sartre was readily applying the theoretical concepts of Critique de la raison dialectique: "the only possible means of communication with the Others, as they are already serialized, is the serial unity of the mass media" (582). ${ }^{7}$ There was 
one major difference with his declaration of 1946; Sartre was no longer trying to preserve the status of the written work, nor was he speaking in the name of the universal class, the ruling class. He pledged his public support for the students' movement (Contat and Rybalka 462-63). He spoke to the students who occupied the Sorbonne. He granted an interview to RadioLuxembourg where he stated that, regardless of the political affiliation of any government, violence was the only option for the students who wanted radical change. He justified the violence of the students in the name of the violence perpetrated against them. For him, the only rapport they could have with the university was to destroy it, and in order to do so, they had to take to the streets (Contat and Rybalka 463-64). Sartre provided Cohn-Bendit with a political platform by interviewing him: the interview was later published in Le Nouvel Observateur as "L'imagination au pouvoir." Sartre no longer spoke in the name of the oppressed (for example in favour of the people of Vietnam fighting against the American oppressor) but instead was facilitating access of the oppressed to the media so that they could express themselves.

\section{Sarkozy's Appropriation of 1968}

Nicolas Sarkozy is a member of the centre-right Union pour un mouvement populaire (UMP). Nationally, Sarkozy first created a sensation as a twenty year old youth delegate at a Gaullist rally in Nice in June 1975. According to Gordon, his 1975 speech was powerful because it attempted to appropriate the language of youth and revolution away from the gauchistes: "to belong to the Gaullist youth is to be a revolutionary, but not like those who are professional demonstrators." 8 This Sarkozian strategy of appropriating the language of youth and revolution 
will be repeated again and again. He co-opts concepts and language from left-wing politicians and manipulates them to his ideological advantage. While Sarkozy was Minister of the Interior, a controversy occurred in November 2005 with film director Mathieu Kassovitz (who produced the film La haine in 1995) over the crisis in the banlieues (the working class suburbs comprising cités or estates, inhabited by a high proportion of people from ethnic minorities, that replaced shanty-towns). ${ }^{9}$ In this instance, I believe that more can be gleaned from the medium than from the argument itself. Sarkozy responded to Kassovitz's internet blog which blamed the government, the police, and also Sarkozy as Minister of the Interior for recent crises in the banlieues. Sarkozy's response to Kassovitz's internet blog is an illustration of what Sartre had said about using all means of communication possible in order to reach the serialized masses: language as praxis. It was pioneering for Sartre to use radio and newspapers in the late 1940s; in the twenty-first century, the internet is the equivalent medium.

There is a general consensus, both in France and abroad, that no French politician has ever figured in the media as much as Sarkozy. His opening statement in his blog's response is that he believes in the virtue of debates and exchanges, and his closing statement invites Kassovitz to pursue their verbal exchange. He claims to be against la langue de bois (political cant) which he blames partly for the rise of extremism in France. May '68 activists were also in favour of the democratization of language, so that it would not remain an elitist domain. In engaging with a young French filmmaker recognized for his sympathies with the Left, Sarkozy is also trying to reach out to a younger, more marginal audience, as opposed to the one traditionally associated with right-wing politicians. He is widening his net, not as a new intellectual, but as a 
new kind of politician. This is underlined by the details of his argument. He introduces the concept of positive discrimination, something that previous French governments, including Socialist ones, have always shunned. He is also in favour of the right of foreigners to vote in local elections, and he promotes a heterogeneous France encapsulated in his trademark slogan: La France plurielle. In the piece, we see him denouncing the supposed equality in France, which is only window-dressing. Inequality was a value at the heart of May '68 opposition. Exclusion and discrimination on the grounds of race were to become important post-' $68 .^{10}$

\section{Sartre's Engagement with 1968}

In order to differentiate between Sartre and Sarkozy, it is necessary to return once again to Sartre. As reported in Cohen-Solal's biography of Sartre, Alain Geismar, one of the student leaders, later said that when he went with some comrades to meet Sartre and Beauvoir at the beginning of the riots, they did not truly have an exchange that day. He had the feeling that they listened, but that they did not understand (Cohen-Solal 586). This concurs with Sartre's own analysis in On a raison de se révolter published in 1974. He acknowledges that he supported the students' movement but, in actual fact, he did not understand it (On a raison de se révolter 63). Whereas May '68 seemed to be temporarily forgotten by French society when traditional summer holidays took over, Sartre was one of the few intellectuals who continued to reflect upon it. The first lesson he drew from these events was the betrayal by the PCF, writing in July 1968 that it had betrayed the revolution, and was objectively on the same side as de Gaulle. He accused the Communist-dominated Confédération générale du travail of doing everything it 
could to prevent contact between workers and students ("M. J.-P. Sartre: le Parti communiste a trahi la révolution de mai" 7). Beauvoir wrote in her memoirs that the Communists had been quick to condemn in L'humanité the German anarchist Cohn-Bendit (Beauvoir, Tout compte fait $50)$.

When Soviet tanks invaded Czechoslovakia in August 1968, Sartre condemned both this invasion and the PCF. This final breakdown of Sartre's relationship with the Communists opened up new possibilities for him. Until then, he had always believed that the Communist Party was the party of the workers. In order to communicate with the workers, one had to use the mediation of the Communist Party. The students proved that one could dialogue with the workers without passing through the mediation of the PCF. Convinced that the Communist Party did not want a revolution, Sartre endeavoured to conquer the two audiences which had always eluded him, namely youth and workers ("I Communisti hanno paura della rivoluzione"). Sartre started to grant more and more interviews to young people, and he himself remembered the moment when he began to make sense of May '68 during a discussion with young people in Italy during the summer of 1968 (On a raison de se révolter 63$){ }^{11}$

An important incident took place in February 1969 when Sartre was one of the speakers at a debate organized by students. As he was about to speak, he found a note on his desk which read: "Sartre, be clear, keep it short: we want to discuss the tactics" (Situations, VIII 240). ${ }^{12}$ In On a raison de se révolter, a record of discussions between Sartre, Pierre Victor and Philippe Gavi, recorded in 1972 and published in 1974, Sartre analyzes how this event aided his own philosophical evolution. He says he did not have anything to say in this meeting called to discuss 
practical matters. His presence was scandalous since he was neither a professor nor a student, his intervention could only be construed as that of a star; he had spoken as a traditional intellectual, opposing the universal to the particular (Sartre, On a raison de se révolter 66 ).

Subsequently, Sartre began to question his status as a traditional intellectual. In her memoirs, Beauvoir testified that he thought about the role of the intellectual to the point of "breaking bones in his head" (Beauvoir, La cérémonie des adieux 5 ). ${ }^{13}$ To the traditional intellectual, he opposed the new intellectual, who denies in himself the intellectual moment to try to find a new popular status; the new intellectual seeks to blend with the masses so that true universality can triumph (16-17). Over the next few years, Sartre would support and facilitate the publication of La cause du peuple, and Libération, so that the masses could express themselves. As he explained in an interview: "Henceforth I consider myself available for all the suitable political tasks which will be required of me" (Sartre, Situations, VIII 470). ${ }^{14}$ Nevertheless, everything was not clear-cut, as we learn in Autoportrait à soixante-dix ans. Sartre admitted that almost two years after May '68 he was still thinking about what had happened, and that he had not really understood. What did these young people want, and what role could vieux cons such as himself have (Situations, X 185)?

In 1971, during one of the popular tribunals held by the Maoists, Sartre insisted on the role of the masses, from object (spectator) to subject (actor). In his foreword to Michèle Manceaux's Les Maos en France, Sartre pointed out that the workers, up until then objects of capitalist authoritarianism, had become, for a moment, the subjects of their own history (Situations, $X$ 45). Sartre subsequently pushed his analysis further in an interview with Leo Fretz 
where he spoke about a society without power becoming an ethical society because a new form of freedom is established, which is the freedom of the reciprocal relations of persons in the form of an "us" (Fretz 233). This "us" Sartre endeavoured to put into practice with Victor and Gavi by recording their discussions and publishing the end result as a book.

Sartre was to further develop the notion of "us" in the context of writing. He devoted the last five years of his life to writing a book of dialogues with Pierre Victor (Benny Lévy), Pouvoir et liberté, where he continued to draw lessons from May '68: “Those who made May '68 happen ... demanded everything: freedom. They did not ask for power ... because ... it is the very social structure which allows for the exercise of power which we need to do away with" (Situations, $X$ 184). ${ }^{15}$

\section{The Aftermath of May 1968}

May '68 has long been the subject of revisionist politics. As Reynolds demonstrates, respected intellectuals from both sides of the political spectrum, such as Régis Debray, Luc Ferry and Gilles Lipovetsky, have all drawn attention to some negative aspects of May '68, from furthering the dominance of capitalism to being responsible for the (narcissistic) individualism of the 1980s. ${ }^{16}$ The headlines following Sarkozy's speech at Bercy on $29^{\text {th }}$ April 2007 concentrated on one particular phrase: "I want to turn the page on May '68" ("Je veux tourner la page de Mai 68”). Sarkozy's speech, in fact written by Henri Guaino, an economist, needs only a cursory glance to illustrate that some of the values of May '68, and some of the lessons Sartre learned from that event, are still being promoted in Sarkozy's discourse ("Pourquoi un tribunal populaire 
contre la police?"). The context surrounding his speech is important: he was making a direct appeal to voters on the eve of the second round of the presidential elections where he ran against Ségolène Royal, the Socialist candidate. He wanted to broaden his appeal to the voters and to be inclusive of all French people, even those who in the past had never been his supporters.

The Bercy speech is a typical illustration of Sarkozy co-opting left-wing political tools and concepts, and then twisting them for his own ideological end. Sarkozy is widely acknowledged as someone who does not adhere to boundaries, and not only between public and private spheres. This can be seen in a positive light, as a new type of politician, or in a negative one, as someone unprincipled and disingenuous. One of his leitmotivs is that he wants to be "the candidate of the people." Politics is there to give the people hope, so that they can become again actors in their own history. Sarkozy has realised that politics must once more reflect the wishes of those who have lost the strength to want things. One can almost hear Sartre talking about reciprocity and the fact that the masses are no longer objects (spectators) but subjects (actors). During his campaign, Sarkozy went to meet the masses. He argues that everyone always pretends to speak in their name when this is not the case, that no one ever really speaks to them, and that no one ever does anything for them, as if the masses should be forever sidelined, excluded from power and decision-making. He mentions that, during his campaign, he went to meet and talk with as many French people as possible, from all possible walks of life. Again, this is an illustration of language as praxis. He singles out young people, condemned to have a worse standard of living than their parents, and whose qualifications are not enough to get a job. He acknowledges that they are resentful of being discriminated against, be it for the colour of their 
skin or the milieu they come from. He says he has also heard the voices of those who are angry at a Republic that does not keep its promises of equality and fraternity. This rhetoric is consonant with May '68 aspirations; again I am not claiming that Sarkozy is a May '68 revolutionary but that he has exploited May '68 to serve his own aspirations.

Sarkozy has met all these anonymous and ordinary people that nobody pays any attention to, that nobody listens to, that nobody wants to hear. Unlike Sartre, whose ultimate aim was to blend with the masses, Sarkozy wants to speak for them, to be their spokesperson, using "us" twenty-two times during the Bercy speech. This quest for power directly contradicts Sartre's line of inquiry in Pouvoir et liberté which consisted in eradicating the very social structures which allowed the exercise of power. In his polemic with Kassovitz, Sarkozy had already argued that he spoke for the majority of French people, claiming to represent the majority of families and young people. While Sartre had warned of the need to be wary of the distinction between the particular and the universal, Sarkozy profits from a slippage between the two. He projects himself as a new politician who tries to find a new popular status. The future President is at pains to stress that he is not interested in meeting those who do not want to share, who seize all the benefits and who feel they owe nothing to their country. Again, this is akin to criticising the very social structures Sartre wanted to eliminate after May '68 but this is where Sarkozy is dangerous. While it may appear that Sarkozy is attacking the rich, he is in fact using this rhetoric to attack people on social benefits, people at the margin of society, and people who, he claims, have no sense of civic duty. 
Sarkozy speaks about an identity crisis in France. He goes so far as to claim that people's doubt is "existential," an echo of Sartrean existentialism, when human beings realize that their life is contingent. As part of Sartre's theoretical reflections in Critique de la raison dialectique, the philosopher, now strongly influenced by Marxism, was asking himself what unites people, introducing the concepts of seriality, praxis, and alienation. Against the practico-inert and seriality was the group, where reciprocity appeared, and which became a group-in-fusion under certain circumstances such as to counteract adversity—-the essential characteristic of the groupin-fusion being the resurgence of freedom (Critique de la raison dialectique 154, 425). Sarkozy is rhetorically asking himself the same questions, but without the philosopher's rigor and method. What is a people? What does the future hold? What unites (French) people? How can they build together? How can they live together? But his answer precedes his questioning and lies in his political project.

\section{The Legacy of May 1968}

One of the cornerstones of May '68, of the Maoist movement in France and of the Gauche prolétarienne is the discovery of the power of the masses. In the midst of the above interrogations, Sarkozy evokes the power of the masses. According to him, this power can be used for better or for worse, and in order to use this power for the better, he introduces the notion of ethics in politics. This will be the platform from which he will launch his attack on May '68.

Sarkozy proceeds to argue that ethics disappeared with May '68, that all values were the same and that there were to be no differences between right and wrong. This is a staggering 
misinterpretation of May '68. And here Sarkozy yet again blurs boundaries. He stretches the definition of ethics. Later in his speech it becomes clear that the value he wants to promote is that of work; the crisis of work is a moral crisis due mostly to May '68. Sarkozy wants to rehabilitate work. If we go back to Critique de la raison dialectique, Sartre describes work as a free praxis interacting with the surrounding matter (369). It is only because of the capitalist system and because of material scarcity that work is a cause of alienation and exploitation. Sarkozy's argument has a logic of its own. With ethics come authority, work and nation; duty over rights. This is not dissimilar to the Petainist discourse of the Vichy government in France (Travail, famille, patrie). A commentator on this paper, Philip Knee is surprised by this comparison between Sarkozy and Pétain, and objects that there is nothing wrong with work as a value. I make this very point above using Sartre but the context of Vichy France was quite different. Pétain argued that France had become too preoccupied with workers' rights during the Front populaire in the late 1930s and that instead of rights, one had to go back to duties. Travail, famille, patrie is a triptych that denies the rights of the individual for the greater good of the (Catholic) country. And the most powerful argument is that during World War II, the French economy became a vital part of the German war machine, with a large proportion of the French GDP being given to Nazi Germany, rising from 20\% to 50\% of official GDP between 1940 and 1943. Sarkozy denigrates the May ' 68 movement by scorning workers' rights and wanting to replace rights with work. ${ }^{17}$ "Work" is never defined but, presumably, Sarkozy means paid work or employment, in which case he is denying all unpaid labour, including that of mothers. Finally, 
while stopping short of calling his political manifesto a revolution, Sarkozy calls it "a moral and intellectual reform.",18

Economy of space prevents me from going into intricate details but many of Sarkozy's criticisms levelled at May ' 68 are unjustified, including when he reproached May '68 for having disposed of the school system of Jules Ferry (the system of compulsory primary education introduced in 1881), concluding that, between Jules Ferry and May '68, the left had chosen May '68. ${ }^{19}$ What provoked the biggest reaction in the French press was Sarkozy claiming that May '68 introduced cynicism into French society and politics, that it was to blame for the cult of money, short-term profit, speculation, and all the pitfalls of financial capitalism. In an extraordinary leap, May '68 was said to be responsible for the immorality of capitalism, including so-called golden handshakes ${ }^{20}{ }^{20}$ As Dhombres pointed out, May '68 demonstrators went to the Stock Exchange in Paris to burn it down, not to buy hedge funds (Dhombres). Forced to retreat from these claims, Sarkozy lambasted all politicians who claimed the heritage of May '68. ${ }^{21}$ Finally, he moved on to attacking the left, which he continues to present as the bedrock of May '68 values. Sarkozy claimed that the left had paralysed France, and the poorest workers were its main victims (and by implication Sarkozy was their defender). Not unlike Sartre after May '68, Sarkozy is trying to appeal both to young people, and to disadvantaged classes. Le Goff, a sociologist and author of Mai '68, l'héritage impossible, reacted to the Bercy speech by pointing out that France had been wavering between fascination with and rejection of May '68 for thirty years. ${ }^{22}$ Sarkozy plays on both tendencies; he uses and promotes through distortion many of the values associated with the events, while trying to leave behind its heritage. 
In the middle of the Algerian war, Sartre had said that the greatness of a nation is measured not by how much blood it sheds, but by how many humanitarian problems it solves ("Les grenouilles qui demandent un roi" 127). The final part of Sarkozy's speech bears a further connection with May '68, but with another twist. According to Sarkozy, once his reforms are accomplished, France will be reconstructed as a fraternal republic (this expression introduces a gender bias: where is the sorority?). It represents a dream never realized since the first day France became conscious of its existence as a nation. ${ }^{23}$ Sarkozy now uses the concept, not in a national context, but in a global context. He wants to be president of a country that defends freedom not only at home but also in the world. He justifies this by saying that it is France's vocation and destiny. In fact, he wants to be the president of Human Rights. So that there is no equivocation, he states that every time a woman or a child is mistreated or battered (martyrisée) in the world, he wants France to be by their side. He then proceeds to give five examples of women's oppression before pledging that he wants every battered woman in the world to be given France's protection by giving her the possibility of becoming French. Quite a number of commentators observed that Sarkozy had never acknowledged the positive impact of May '68 on women's liberation (Cohn-Bendit and Royal). Now, he wants to be the knight in shining armour defending oppressed women worldwide. Sartre would shudder at all this-not content with speaking for all French people, Sarkozy is now claiming to embody the entire French nation as a global President of Human Rights, promoting France to the position of global Ministry of Justice. In 1958, when de Gaulle called a referendum, Sartre explained that if God existed and if he had to choose between God and de Gaulle when casting his vote, he would vote for God, as 
He is more modest than de Gaulle ("La constitution du mépris" 107). My guess is that he would have used the same logic to describe Sarkozy.

For Sarkozy, France is more than a territory; France is an ideal, indefatigably pursued by its great people, who, from the outset, have believed in its ideals, in their capacity to transform the world and to create happiness for the whole of humanity. Sarkozy sees himself as the catalyst for France to recover its universal values, which should form the basis for its internal and external politics.

Before concluding the speech, Sarkozy condemns those who have criticised him, and in the process he reveals his true motive. His detractors are the same as those who demonstrated against de Gaulle in 1958, shouting: Le fascisme ne passera pas. It is timely to remember that some of these de Gaulle supporters were OAS members (Organisation de l'armée secrète) who were also shouting Fusillez Sartre. Indirectly, Sarkozy is claiming de Gaulle's heritage, which is a direct appeal to another particular group of voters. 1958 was a time of political crisis in France, mostly due to events in Algeria, then constitutionally part of France. De Gaulle was recalled to power, on the understanding that he would keep Algeria French. It is no coincidence that Sarkozy compares himself to de Gaulle because the role he proposes for France, as detailed in the final part of his speech, is tainted by a colonialist discourse. Le Goff rightly qualifies this last manoeuvre as pure nostalgia, made in order to claim that what was in place before May '68 was preferable ("Mai 68. Retour acide"). Analysts of May '68 have long established that the students' movement is to be understood in a long line of various protest movements in the 1960s such as decolonisation, the Vietnam War, sexual liberation and so forth. ${ }^{24}$ Sarkozy wants to dispose of 
May '68 because he craves a golden age of colonialism, or rather he has a nostalgic hankering for colonial rule. ${ }^{25} \mathrm{He}$ wants France to "transform the world and to create happiness in the whole of humanity" while giving lessons on human rights. ${ }^{26}$ In his first blog on the banlieues, Kassovitz referred to Sarkozy as a "puny, would-be Napoléon." ${ }^{27}$ He anticipated the Bercy speech and Sarkozy's appearance on the front covers of both Stern and The Economist in 2007.

If one contrasts the rhetoric used by Sarkozy as Minister of the Interior and during the presidential campaign on the one hand, with his record as President on the other hand, differences start to open up. The "us" has been largely replaced by the "I." Sarkozy is often seen in the media mixing with the rich and powerful. He has given himself a $170 \%$ pay increase and promised that he would raise the French people's standard of living. Yet he then turned round and said the coffers were empty while giving tax concessions to the very rich. How could one explain such discrepancies? Sarkozy should have heeded Sartre's warning in Power and Freedom, about the corrupting effect of power and its antithetical relationship to freedom, though I would agree with Knee that one cannot make a straightforward comparison between a politician involved in pragmatics and a philosopher involved in theoretical ruminations (which Knee qualifies as imaginary politics, using the slogan L'imagination au pouvoir).

I want to conclude with an extract from the book by Yasmina Reza, L'aube, le soir ou la nuit (Dawn, Evening or Night):

Nicolas: (repeating a phrase from his Bercy speech) Between Jules Ferry and 68, they chose $68 \ldots$ Well, it verges on bad faith.

Yasmina: I am glad to hear you say it...

Nicolas: (laughing) Yes. It's even terrifyingly in bad faith, but in the end, you have to go for it! ${ }^{28}(\text { Reza } 159)^{29}$ 


\section{Notes}

${ }^{1}$ In the original French: "Ensemble tout devient possible." This political slogan comes from the UMP, Sarkozy's party.

2 For a comprehensive overview of this remark, see Gordon's "Liquidating May '68? Generational Trajectories of the 2007 Presidential Candidates."

3 [Editor's note: In this article, all translations are the authors. The French is included in a footnote in each case.] "Il ne convient pas de s'abaisser pour plaire, mais au contraire, de révéler au public ses exigences propres et de l'élever, petit à petit, jusqu'à ce qu'il ait besoin de lire."

4 “Dès lors que j'existe, j'établis une limite de fait à la liberté d'Autrui."

5 “[L]a voix humaine se donne comme praxis et constitue l'auditeur comme l'objet de la praxis ... c'est une relation univoque d'intériorité."

6 "Il ne doit pas confondre l'universel avec l'effort singulier d'un groupe social particularisé."

7 "Le seul moyen de communication possible avec les Autres, en tant qu'ils sont déjà sérialisés, c'est l'unité sérielle des mass media."

8 “Être jeune gaulliste, c'est être révolutionnaire, révolutionnaire pas à la manière de ceux qui sont des professionnels de la manif" (Gordon, "Liquidating May '68? Generational Trajectories of the 2007 Presidential Candidates" 153).

9 http://www.u-m-p.org/site/index.php/ump/s_informer/tribunes/nicolas_sarkozy_repond_a_ mathieu_kassovitz. Kassovitz's original article and his response are to be found at: www.mathieukassovitz.com, accessed on 11 December 2009.

${ }^{10}$ I should make it clear at this point that I am not arguing that Sarkozy is a closet May '68 exponent; I would rather agree with Philipp Knee's formulation that there is an echo of May '68 values in Sarkozy's responses.

${ }^{11}$ See my Sartre médiatique. La place de l'interview dans son œeuvre. Paris: Minard, 1992.

12 "Sartre, sois clair, sois bref: nous voulons discuter des consignes à adopter."

13 "Casser des os dans sa tête."

14 "Maintenant je me considère comme disponible pour toutes tâches politiquement justes qui me seront demandées." 
15 “Ceux qui ont fait Mai ' 68 ... demandaient tout: la liberté. Ils ne demandaient pas le pouvoir ... car ... c'est la structure sociale même, permettant l'exercice du pouvoir qu'il s'agit de supprimer."

${ }^{16}$ See Chris Reynolds, "May 68: A Contested History”; Alain Badiou, De quoi Sarkozy est-il le nom?; Régis Debray, Modeste contribution aux discours et cérémonies officielles du $X^{e}$ anniversaire; Luc Ferry and Alain Renaut, La pensée 68. Essai sur l'anti-humanisme contemporain; Gilles Lipovetsky, L'ère du vide. Essais sur l'individualisme contemporain.

${ }^{17}$ One is reminded of the sacrifice of the individual for the greater good of the nation.

18 In a thought-provoking article, "The Communist Hypothesis," Alain Badiou argues that beyond the attack on May '68, the specter of communism haunts Sarkozy. He also compares Sarkozy's political discourse to neo-Pétainism on four counts: the alliance of fear and war; the displacement of politics by morality; the paradigmatic function of foreign experience; and the source of the crisis lying in a disastrous past event (32-34).

${ }^{19}$ For a systematic rebuttal of Sarkozy's argument, see Daniel Bensaid, and Alain Krivine, "La haine de 68."

20 See the interview with Cohn-Bendit by Richard Werly, "Par rapport à Mai 68, Nicholas Sarkozy se comporte en pur stalinien." See also "Référence de la gauche, un héritage qui épouvante à droite" and "Mai 68: Sarkozy provoque l'ire de la gauche."

${ }^{21}$ Within weeks of his speech, he would appoint as Minister for Foreign and European Affairs, Bernard Kouchner, one of the symbols of May ' 68 and, at the time, leader of the Communist students' union, not to mention Sarkozy's welcomed support by ex-PCF member, philosopher, André Glucksmann. Glucksmann, Mai 68 expliqué à Nicolas Sarkozy 98.

22 France-Culture. 30 April 2007. Le journal de la mi-journée: http://web2.radiofrance.fr/chaines/france-culture/information/accueil/fiche.php?diffusion_id=52554\&index=5, accessed on 11 December 2009.

${ }^{23}$ One could point out that France is not a nation: it is a country or a state. The French are a nation.

24 See, for instance, Bernard E. Brown, Protest in Paris: Anatomy of a Revolt and Singer, Prelude to a Revolution.

25 http://www.u-m-p.org/site/index.php/s_informer/discours/nicolas_sarkozy_a_bercy, December 2009.

26 “Transformer le monde et [à] faire le bonheur de l'humanité.” 
27 "Petit Napoléon en devenir," http://www.mathieukassovitz.com/blog/2005/11/la-france-denbas.html, 11 December 2009.

28 "Nicolas: (répétant une phrase de son discours de Bercy) Entre Jules Ferry et 68, ils ont choisi 68 ... Bon, c'est limite mauvaise foi ... [another Sartrean concept]

Y.: Je suis contente de te l'entendre dire ...

Nicolas: (il rit) Oui. C'est même terrifiant de mauvaise foi, mais enfin, il faut y aller!"

${ }^{29}$ I would like to thank David Drake and Philip Knee for their judicious comments on this article. Philipp Knee was the commentator for the first version of this paper delivered at the Conference of the Society for Existential and Phenomenological Theory and Culture, University of British Columbia, 3-6 June 2008. I would like to thank him sincerely for his attentive reading of my paper and for having set up such a productive dialogue (and discussion during the conference). A further version of this paper was delivered under the auspices of the Arts and Humanities Research Council (AHRC), Research Networks and Workshops Scheme: "The Relevance of Jean-Paul Sartre Today" at the University of Rikkyo (Japan) in July 2009. The research for this paper was supported by a generous grant from the AHRC.

\section{Works Cited}

Aeschimann, Eric. “Mai 68. Retour acide.” Libération (4 May 2007), 30.

Astruc, Alexandre and Michel Contat. Sartre. Paris: Gallimard, 1977.

Badiou, Alain. "The Communist Hypothesis.” New Left Review, no. 49 (Jan-Feb 2008): 29-42.

—. De quoi Sarkozy est-il le nom? Paris: Editions Lignes, 2007.

Beauvoir, Simone de. La cérémonie des adieux, suivi de Entretiens avec Jean-Paul Sartre. Paris: Gallimard, 1981.

—. Tout compte fait. Paris: Gallimard, 1972.

Bensaid, Daniel and Alain Krivine. "La haine de 68.” Libération, “Rebonds” (3 May 2007).

Brown, Bernard E. Protest in Paris: Anatomy of a Revolt. London: General Learning Press, 1974.

Boulé, Jean-Pierre. Sartre médiatique. La place de l'interview dans son auvre. Paris: Minard, 1992. 
Cohn-Bendit, Daniel and Alain Geismar, "Nous sommes coupables...." Libération, "Rebonds" (2 May 2007).

Cohn-Bendit, Daniel and Ségolène Royal. Lunchtime News, 'Présidentielle: la campagne de l'entre-deux tours sur thème de confrontation et de débat.' http://web2.radio-france.fr/chaines/franceculture/information/accueil/fiche.php?diffusion_id=52554\&index $=5$ Accessed on 11 December, 2009.

Cohen-Solal, Annie. Sartre 1905-1980. Paris: Gallimard, 1985.

Contat, Michel and Michel Rybalka. Les écrits de Sartre. Paris: Gallimard, 1970.

Debray, Régis. Modeste contribution aux discours et cérémonies officielles $d u X^{e}$ anniversaire. Paris: Maspero, 1978.

Dhombres, Dominique. "Une victime cachée de Mai 68.” Le Monde (2 May 2007).

“Entretien avec Epistémon.” Le Monde, supplement to issue no. 7428 (30 November 1986), IV.

Fretz, Leo. "An interview with Jean-Paul Sartre." Jean-Paul Sartre. Contemporary Approaches to his Philosophy. Eds. Hugh J. Silvermann and Frederick A. Elliston. Pittsburgh: Duquesne University Press, 1980. 221-39.

Ferry, Luc and Alain Renaut. La pensée 68. Essai sur l'anti-humanisme contemporain. Paris: Gallimard, 1988.

Geismar, Alain. Mon Mai 1968. Paris: Perrin, 2008.

Glucksmann, André. Mai 68 expliqué à Nicolas Sarkozy. Paris: Denoël, 2008.

Gordon, Daniel, "Liquidating May '68? Generational Trajectories of the 2007 Presidential Candidates." Modern and Contemporary France 16, no. 2 (May 2008): 143-59.

“I Communisti hanno paura della rivoluzione.” L'Espresso (Milan), no. 34 (August 1968).

Le Goff, Jean-Pierre. Mai 68, l’héritage impossible. Paris: La Découverte, 1998.

"L'imagination au pouvoir, entretien de Jean-Paul Sartre avec Daniel Cohn-Bendit." Le Nouvel Observateur (20 May 1968). 
Lipovetsky, Gilles. L'ère du vide. Essais sur l'individualisme contemporain. Paris: Gallimard, 1983.

“Mai 68: Sarkozy provoque l'ire de la gauche," Le Figaro (30 avril 2007).

“M. J.-P. Sartre: le Parti communiste a trahi la révolution de mai," Le Monde (16 July 1968).

Nivelle, P. and E. Karlin. “Nicolas Sarkozy: secrets de jeunesse.” L’Express (5 October 2006).

Occhino, Filippo, Kim Oosterlinck, and Eugene N. White. "How Occupied France Financed Its Own Exploitation in World War II.” American Economic Review 97, no. 2 (May 2007): 295-99.

"Pourquoi un tribunal populaire contre la police?" La Cause du peuple-J'accuse, No. 6 (21 June 1971).

"Référence de la gauche, un héritage qui épouvante à droite, réactions de François Hollande et Ségolène Royal." Le Figaro (30 April 2007).

Reynolds, Chris. "May 68: A Contested History.” Sens Public, October 2007, http://www.senspublic.org/article.php3?id_article=472, accessed 18 December 2009.

Reza, Yasmina. L'aube, le soir ou la nuit. Paris: Flammarion, 2007.

Sartre, Jean-Paul. "Autoportrait à soixante-dix ans." Situations, X. Paris: Gallimard, 1976. 133226.

—. Critique de la raison dialectique. Paris: Gallimard, 1960.

—. "La constitution du mépris." Situations, V. Paris: Gallimard, 1964. 102-112.

—. "Le fantôme de Staline." Situations, VII. Paris: Gallimard, 1965. 144-307.

—. "L'anthropologie." Situations, IX. Paris: Gallimard, 1972. 83-98.

—. "Les communistes et la paix." Situations, VI. Paris: Gallimard, 1964. 80-384.

—. "Les grenouilles qui demandent un roi." Situations, V. Paris: Gallimard, 1964. 113-44.

—. "Les Maos en France." Situations, X. Paris: Gallimard, 1976. 38-47. 
—. L'Être et le néant. Paris: Gallimard. 1943.

—. "Plaidoyer pour les intellectuels." Situations, VIII. Paris: Gallimard, 1972. 375-455.

—. “Qu'est-ce que la littérature?" Situations, II. Paris : Gallimard, 1948. 55-330.

Sartre, Jean-Paul, Pierre Victor, Philippe Gavi. On a raison de se révolter. Paris: Gallimard, 1974.

Singer, Daniel. Prelude to a Revolution. London: Jonathan Cape, 1970.

Werly, Richard. "Par rapport à Mai 68, Nicolas Sarkozy se comporte en pur stalinien." Le Monde (1 May 2007). 